\title{
Nanoscale
}

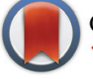

CrossMark

\&click for updates

Cite this: Nanoscale, 2015, 7, 7470

Received 17th February 2015,

Accepted 25th March 2015

DOI: $10.1039 / c 5 n r 01133 g$

www.rsc.org/nanoscale

\section{Mechanisms of nanosilver-induced toxicological effects: more attention should be paid to its sublethal effects}

\author{
Zhe Wang, ${ }^{a, b}$ Tian Xia*c and Sijin Liu*a
}

Due to its unique physicochemical properties and remarkable antimicrobial activity, nanosilver ( $\mathrm{nAg}$ ) is increasingly being used in a wide array of fields, including medicine and personal care products. Despite substantial progress being made towards the understanding of the acute toxicity of nAg, large knowledge gaps still exist on the assessment of its chronic toxicity to humans. Chronic effects of nAg, typically at low doses (i.e. sublethal doses) should be different from the acute toxicity at high doses (i.e., lethal doses), which is analogous to other environmental pollutants. Although a few review papers have elaborated the findings on nAg-mediated toxicity, most of them only discussed overt toxicity of $\mathrm{nAg}$ at high-level exposure and failed to evaluate the chronic and cumulative effects of nAg at sublethal doses. Therefore, it is necessary to more stringently scrutinize the sublethal toxicity of nAg under environmentally relevant conditions. Herein, we recapitulated recent findings on the sublethal effects of nAg toxicity performed by our groups and others. We then discussed the molecular mechanisms by which nAg exerts its toxicity under low concentrations and compared that with nAg-induced cell death.

\section{Introduction}

With the rapid development of nanotechnology, a variety of engineered nanomaterials, including carbon nanotubes, gold nanoparticles, silver nanoparticles and quantum dots, have been extensively explored for applications in biology and medicine. ${ }^{1-4}$ Among these engineered nanomaterials, nanosilver (nAg) is the most commonly used inorganic metal-based particle. nAg, also referred to as silver nanoparticles, is a cluster of silver atoms that are at least one dimensional with a size ranging from 1 to $100 \mathrm{~nm} .{ }^{5}$ Compared to its bulk counterpart, silver nanoparticles exhibit distinct physical, chemical and optical properties, as well as excellent antimicrobial activities, and they are widely used in a myriad of real life applications such as catalysis, electronics, food packaging materials, textiles, cosmetics and room sprays. ${ }^{5-8}$ In fact, more than 400 nAg-related products (over $30 \%$ of total nanoproducts) have been in the market around the world. ${ }^{9,10}$ One of

\footnotetext{
${ }^{a}$ State Key Laboratory of Environmental Chemistry and Ecotoxicology, Research Center for Eco-Environmental Sciences, Chinese Academy of Sciences, Beijing. 100085, China.E-mail: sjliu@rcees.ac.cn, txia@ucla.edu;

Fax: +8610-62849330, +1310-9833359; Tel: +8610-62849330, +1310-9833359

${ }^{b}$ Department of Integrative Physiology and Pathobiology, Tufts University School of

Medicine, Boston, Massachusetts 02111, USA

${ }^{c}$ Division of NanoMedicine, Department of Medicine, University of California,

Los Angeles, California 90095, USA
}

the extensive applications for $\mathrm{nAg}$ is in biomedicine such as wound dressing, coating of implantable devices, medical imaging and drug delivery. ${ }^{6,11}$ Specifically, $\mathrm{nAg}$ has been added as a desirable component in a number of clinical products, including Actioat ${ }^{\mathrm{TM}}$, Silverline ${ }^{\circledR}$, SilverSorb ${ }^{\circledR}$ and ON-Q SilverSoaker ${ }^{\mathrm{TM}} .{ }^{4}$ With the increasing usage of $\mathrm{nAg}$ in consumer and medical products, it is crucial to comprehensively understand its potential toxicity and the mechanism of toxicity under environmentally relevant conditions to promote its safe use in diagnostics and therapeutics.

Exposure dosages are critical for the toxic assessment of environmental pollutants, and nanomaterials are not different. ${ }^{12,13}$ It should be noted that there are differences between nanoparticle and heavy metal pollutants in ionic form, although both of them induce toxicity in a dose-dependent manner. Their differences are mainly in the cellular uptake pathways and intracellular behaviors through which nanoparticles and metals pose toxicity to cells and organisms. Compared to metal ions, metal-based nanoparticles are easier to pass through biological barriers and cell membranes. ${ }^{14}$ In addition, metal nanoparticles have a large surface that has the potential to adsorb toxic substances and biological molecules on their surface, resulting in an increased reactivity, availability and toxicity. ${ }^{15}$ It has long been known that the chronic toxicity caused by environmental pollutants could be very different from their acute toxicity, as listed in Table 1. Highdose exposure to inorganic and organic pollutants such as 
Table 1 Toxicity induced by the representative environmental pollutants at the acute high dose and the chronic low dose

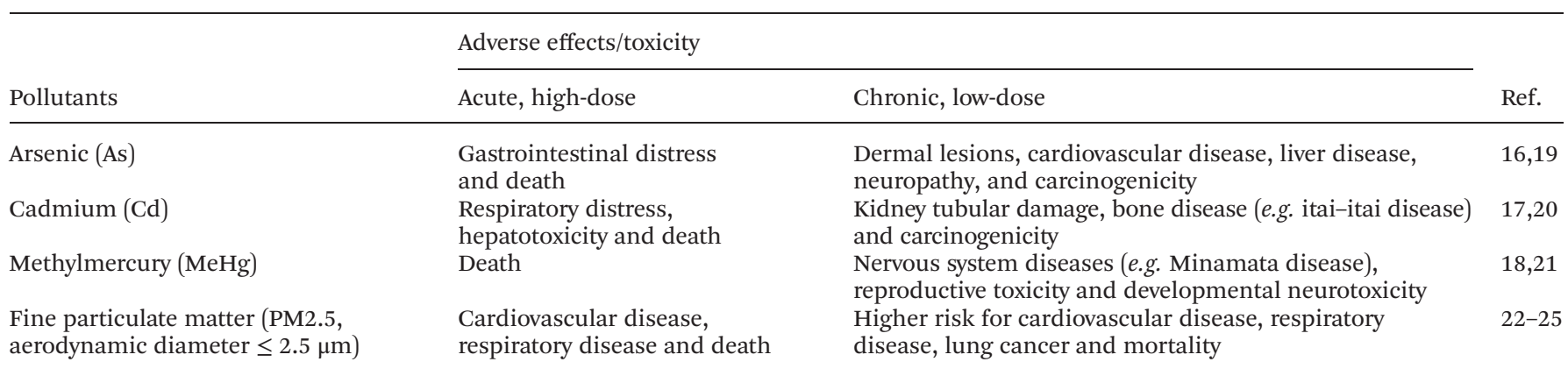

arsenic, cadmium and methylmercury in occupational settings or by accident usually causes acute and often fatal effects, ranging from gastrointestinal distress or respiratory distress to death. ${ }^{16-18}$ In contrast, long-term exposure to these pollutants from contaminated food and drinking water can induce chronic organ injuries, diseases and cancer in adults, ${ }^{19,20}$ as well as lead to the development of toxicity in the fetus even when the mother shows no poisoning symptoms. ${ }^{18,21}$ Ambient particulate matter (PM) is another example. Long-term cumulative exposure to PM can cause cardiovascular diseases, respiratory diseases, and cancer in susceptible humans and animals, compared with air pollution, which leads to respiratory distress and death. ${ }^{22-25}$ Moreover, the signaling pathways that are activated at low doses are distinct from that activated at high doses when cellular and organismic defense systems are overwhelmed. ${ }^{12}$ Therefore, the health risk from exposure to a low dose of environmental pollutants, which is more relevant to real-world situations, should be particularly considered.

The most common routes of $\mathrm{nAg}$ exposure to humans include inhalation, skin contact, food ingestion and medication. ${ }^{11,26,27}$ After translocation into the circulatory system, $\mathrm{nAg}$ could be transported to various internal organs, causing adverse effects in susceptible organs. ${ }^{5,28}$ Clinical research and animal studies reported that the adverse effect of nAg is systemic neurotoxicity and death after acute exposure, and argyria, local inflammation, and organ damages after chronic exposure. ${ }^{5,27,29,30}$ At the cellular level, nAg can cause overt cytotoxicity at high concentrations, including abnormalities of cellular morphology, enhancement of membrane permeability, significant decline of cell growth and even cell death. ${ }^{31-33}$ If the exposure levels are relatively low, no cell death can be observed; however, nAg can disturb the normal functions of cells at the molecular level. ${ }^{34-36}$ These preliminary studies suggest that low-dose nAg has the potential to pose chronic health hazards that warrant attention in future studies.

To date, most studies on silver focused on the acute effects or overt toxicity of $\mathrm{nAg}$ at lethal doses without considerable attention being paid to sublethal doses. In the current review, we recapitulate the potential detrimental effects of $\mathrm{nAg}$ under lethal and sublethal exposure conditions and highlight the molecular mechanisms responsible for nAg-induced sublethal cellular responses. It should be noted that the description of low doses in this review represents not necessarily the physiologically relevant doses, but the exposure levels, in which nAg induces adverse effects on animals and cells without lethal effects.

\section{What are the sublethal effects of $n A g$ ?}

It is well known that the toxicity induced by $\mathrm{nAg}$ is a dosedependent process. ${ }^{26} \mathrm{nAg}$ added into consumer products and coatings will slowly, mainly through laundering, release from its substrate material into domestic wastewater. It has been reported that nearly one-third nAg-containing products in the market in 2007 had the potential to disperse silver or silver nanoparticles into the environment. ${ }^{37}$ Although the exact concentration of $\mathrm{nAg}$ exposed to human has not been reported to date, it should be of relatively low levels that can be deduced from silver exposure levels under environmental and everyday settings. The probability for human daily exposure to very low levels of silver is mainly from food and drinking water, and less from air. ${ }^{5,26}$ The average concentration of silver is $0.2-2 \mu \mathrm{g}$ $\mathrm{L}^{-1}$ in surface water of rivers and lakes, 200-300 $\mu \mathrm{g} \mathrm{kg}^{-1}$ in soils, and less than $1 \times 10^{-6} \mu \mathrm{g} \mathrm{\textrm {L } ^ { - 1 }}$ in air. ${ }^{38}$ Given the extremely low background concentrations of silver in the environment, the addition of nAg due to human activities, even a small mass, will result in significant environmental risks. ${ }^{37}$ Moreover, silver in the form of nanoparticles exhibits an enhanced capability to penetrate protection barriers and tissues, and thus gain access to cells and biological molecules in the body, which results in acute or chronic effects such as organ injuries.

\subsection{Effects of nAg on the environment}

It has been suggested that the leached $\mathrm{nAg}$ will first pass through sewage treatment plants, in which the majority of $\mathrm{nAg}$ is precipitated in the sludge and the minority left in the effluent will reach the aquatic environment. ${ }^{39}$ If the sludge from sewage plants is used in soil as a fertilizer or deposited onto a landfill, nAg will deposit into the soil. ${ }^{40}$ The disposal of $\mathrm{nAg}$ into water and soil will raise risks to aquatic and terrestrial organisms. The potential risk of $\mathrm{nAg}$ lies in their bioaccumulative 
ability and the unique properties of nanoparticles. Moreover, $\mathrm{nAg}$ dispersed into the natural environment will undergo further transformation, such as agglomerating, dissolving ionic Ag, reacting with other toxic substances, and/or binding to natural organic matter. For example, humic acid can reduce the aggregation of $\mathrm{nAg}$ and enhance its mobility in natural water. Depending on solar light, $\mathrm{nAg}$ can be regenerated through the organic matter conducted reduction of $\mathrm{Ag}$ ions. These transformations can largely affect the bioavailability and toxicity of nAg.

Silver particles at the nanoscale exert robust inhibitory effects on the growth for a wide spectrum of microorganisms. Numerous studies concerning its strong antimicrobial activity showed that $\mathrm{nAg}$ could induce bacterial death by damaging membrane structure, increasing reactive oxygen species (ROS) levels and enhancing $\mathrm{Ag}$ ion release. ${ }^{41-43}$ Thus, the biocidal silver dispersed into the environment may inhibit the growth of beneficial bacteria in sewage systems and disrupt the normal function of key soil microbial communities. ${ }^{6,40}$ Especially, the contamination of $\mathrm{nAg}$ in water and soil will further raise the possibility of silver resistance in bacteria, a growing concern around the world. ${ }^{6,7}$ Several studies showed that low levels of silver released from wound dressing are more likely to promote resistance than that at high levels, especially if the silver level is sublethal. ${ }^{44-46}$ It has been suggested that nAg under sublethal concentrations may promote bacterial survival rates, although relevant studies are still limited. In the recent study by Xiu and colleagues, $E$. coli cells were exposed to a panel of $\mathrm{nAg}$ of different sizes and coatings for $6 \mathrm{~h}$. They found that the survival rates were improved in the presence of lower concentrations of $\mathrm{nAg}\left(2-7 \mu \mathrm{g} \mathrm{mL}^{-1}\right)$ with $6 \%-21 \%$ higher viability compared to the untreated control group, indicating an apparent hormetic effect. ${ }^{47}$

Moreover, given that silver is the second most toxic metal for aquatic organisms next to mercury, nAg dispersed into the aquatic systems may affect the development of fish embryos at even lower concentrations. ${ }^{37}$ For example, in a study by Lee and colleagues, single nAg particles were observed in zebrafish embryos, including brain, heart, gill arches and tail, resulting in developmental malformations and morphological deformities. $^{48}$ The concentrations used in this study $\left(4-71 \mathrm{ng} \mathrm{\textrm {L } ^ { - 1 }}\right)$ were realistic in terms of what is expected for contaminated waters. Although mortality was observed in a dose-dependent manner, the toxicity of nAg for the development of zebrafish occurs likely at lower concentrations.

Together, it is reasonable to conclude that nAg can be released from commercial products into the environment, where nAg is likely to disrupt bacterial ecosystems and interfere with the development of fish embryos under sublethal concentrations.

\subsection{Effects of nAg on human health and animals}

Because of the effective antimicrobial activity, nAg has been extensively applied in biomedicine, which poses a substantially increased risk to human health. For example, the accidental inhalation of $\mathrm{nAg}$ may occur during the usage of nasal drops for rhinitis treatment. The dermal absorption of $\mathrm{nAg}$ from the wound dressing may take place after local treatment. ${ }^{27}$ Moreover, due to the enhanced permeation and preferential optical property, nAg has emerged as an effective regime for disease therapeutics and can be used to deliver therapeutic compounds or image tumor cells. ${ }^{49-51}$ However, the accumulation of nanoparticles in the target tissues is always a small fraction of the total injected dose, e.g. 1\%-10\% for tumor, whereas majority of the administered particles end up in liver and spleen and ultimately remain in the body. ${ }^{52}$ The internal crystal structure, designed for strong plasmonic resonance properties, may increase the catalytic effect of nanoparticles and thus enhance their adverse effects. ${ }^{53}$ In addition, nAg may have the Trojan horse effect after cellular uptake, in which the particles continue to release silver ions in cells that can bind to proteins overwhelming the antioxidant defense, leading to toxicity. ${ }^{54-56}$

Clinical reports concerning the side effects of $\mathrm{nAg}$ are relatively rare, despite the rapid development of $\mathrm{nAg}$ in biomedical applications. Chronic toxicity of $\mathrm{nAg}$ is accompanied with skin discolouration (argyria), which is a local or systemic effect observed in individuals that are occupationally exposed to $\mathrm{nAg}$, such as people who ingested a nAg suspension, or patients that have been treated with nAg-containing burn dressings. ${ }^{27}$ Fewer cases or studies showed neurological toxicity of $\mathrm{nAg}$ on humans. One clinical case has reported that a 71-year-old man developed myoclonic status epilepticus and coma and death after 5.5 months, resulting from daily ingestion of colloidal silver (a nAg suspension in a liquid) for 4 months. ${ }^{29}$ A localized nerve lesion was observed in a patient after a five-year usage of silver impregnated bone cement in a revisional Christiansen total hip arthroplasty because of a large amount of silver released from the implanted cement. ${ }^{57}$ The higher level of released silver led to a severe local tissue disruption and even necrosis. ${ }^{58}$ The applications of nAg-coated implantable devices and increased release rate of silver suggests that a low concentration of $\mathrm{nAg}$ has potential to incur nerve and tissue damage. ${ }^{6}$

In the literature, many studies have described in vivo toxic effects of nAg using various animal models. ${ }^{5,28}$ It has been demonstrated that $\mathrm{nAg}$ can accumulate in various organs, such as liver, spleen, kidney, heart, lung, olfactory bulb, brain and testes, based on ultrastructural analysis, histological staining and Ag content measurement. ${ }^{5,13,27,59}$ The form of silver in these organs is difficult to determine because the quantification methods, such as ICP-MS, only provide total Ag element concentrations; therefore, they should include both nanoparticles and $\mathrm{Ag}$ ions. ${ }^{5}$ After deposition in the body, short-term or acute effects of $\mathrm{nAg}$ have been reported at relatively high concentrations of its exposure (acute exposure). Death has been observed in rats after oral ingestion of very high-dose colloidal silver (1680 $\mathrm{mg} \mathrm{kg}^{-1}$ ) for four days. ${ }^{5}$ Moreover, Schmaehl and Steinhoff administered rats with an intravenous injection of $\mathrm{LD}_{50}$ amounts of colloidal silver $\left(67 \mathrm{mg} \mathrm{kg}{ }^{-1}\right)$ and observed brown discoloration in the liver, spleen and kidney, lung edema, and death of rats. ${ }^{30}$ At lower concentrations (chronic 
exposure), nAg has been reported to cause different toxic effects without a significant sign of morbidity. Local inflammation and individual organ damage, such as lung abnormalities and liver damage, may occur in exposed animals, upon the absorption of $\mathrm{nAg}$ in lung, skin, or gastrointestinal tract. $^{59-63}$ For example, pulmonary inflammation and mild fibrosis were observed in mice after an inhaled administration of $\mathrm{nAg}$ by oropharyngeal aspiration at lower doses $(0.1,0.5$ and $1.0 \mathrm{mg} \mathrm{kg}^{-1}$ ). The dosage used was environmentally relevant because it was extrapolated from the real life nAg concentrations in the air in a manufacturing facility (range of 5-289 $n g \mathrm{~L}^{-1} \mathrm{nAg}$ in the injection room). ${ }^{13,64}$

It has been found in preliminary studies that nAg more easily crosses the biological barriers in animals, including the blood-brain barrier (BBB) and the placental barrier. For example, inhaled nAg could gain access to the brain through olfactory nerves and/or the $\mathrm{BBB}$, resulting in the alterations of gene expression in the central nervous system of mice. ${ }^{5,12,65}$ Tang and colleagues demonstrated that $\mathrm{nAg}$ could pass through the BBB mainly by transcytosis of capillary endothelial cells and induce astrocyte swelling and neuronal degeneration after subcutaneous administration in rats. ${ }^{66,67}$ In recent studies by our group and other groups, the presence of silver in murine fetuses and rat pups suggested the translocation from maternal blood to embryonic blood via the placental barrier, although the form of sliver (nanoparticle or $\mathrm{Ag}$ ions) was unclear. ${ }^{68,69}$ Our group further demonstrated that $\mathrm{nAg}$ accumulated in embryos could induce pronounced developmental retardation on embryonic day 14.5 (E14.5) following intraperitoneal injection in mice before pregnancy. ${ }^{36}$ Under the current exposure doses (22 and $108 \mu \mathrm{g} \mathrm{kg}^{-1}$ ), the gross toxicity, organ injuries and hematological changes were not observed in the parental mice, except for histological abnormalities in the liver. These studies indicate that low-dose nAg may also elicit chronic toxicity to brains and embryonic development.

In addition to the general toxicity as well as tissue and organ damage in animals, the adverse effects of $\mathrm{nAg}$ on various cells and the corresponding mechanisms have been investigated, which will be discussed in more detail in the next section. Briefly, at high concentrations, nAg can cause overt cytotoxicity via ROS production. In contrast, the low exposure levels of nAg tend to interrupt biological processing and signaling and to disturb the normal functions of organelles at a cellular level, which is not associated with viability reduction or cell death.

The damage of tissues and dysfunction of cells indicate that, similar to environmental pollutants described above, the chronic toxicity of $\mathrm{nAg}$ at low levels is different from its lethal effects at high doses. Although the doses used in previous studies may be comparatively higher, it is difficult to extrapolate these toxic effects to human health risks at the current stage; low-dose $\mathrm{nAg}$, which is more relevant to daily life, appears to be toxic without causing cell death. Given the realistic exposure scenarios for humans using nAg-related products, it is necessary to consider the sublethal toxicity of nAg at low doses. In future studies, lower doses of nAg exposure such as the no observable adverse effect level (NOAEL) and especially the environmental relevant exposure levels should be conducted.

\section{Mechanisms of $\mathrm{nAg}$-induced cytotoxicity}

Herein, we present an overview of the major molecular mechanisms whereby nAg can cause damage to cells and thus organisms. These mechanisms are organized around the cellular responses upon nAg under lethal and sublethal concentrations, as presented in Table 2. In order to highlight sublethal effects of low-dose nAg, we compare its effects to the cytotoxic mechanisms underlying lethal nAg-induced apoptosis and necrosis under high-dose exposure. The major physicochemical properties, including size, shape and surface coating largely contribute, at various extents, to nAg-conducted biological effects. The mechanisms of nAg toxicity can be attributed to released $\mathrm{Ag}$ ions and/or nanoparticles deposited inside the cells and detailed mechanisms mostly include reactive oxygen species (ROS) generation, disruption of energy metabolism and gene transcription. ${ }^{28,41,70,71}$ The damage of membrane integrity induced by extracellular nAg is presumably an additional mechanism responsible for cell death. ${ }^{53}$

\subsection{Physicochemical properties: important factors influencing cellular uptake}

Cellular uptake and subcellular distribution of nAg in cells form the basis for its biological and toxic effects. ${ }^{72}$ For nonphagocytic eukaryotic cells, nAg can be taken up via various endocytic pathways, including (i) clathrin-dependent endocytosis, (ii) caveolin-mediated endocytosis, (iii) clathrin- and caveolin-independent endocytosis, and (iv) macropinocytosis, as depicted in Fig. 1. For phagocytes, including macrophages and monocytes, phagocytosis is the main mechanism responsible for the cellular uptake of $\mathrm{nAg} .{ }^{73,74}$ The different internalization pathways can be elucidated by treatments with selective pharmacological inhibitors, dominant negative mutants, as well as gene knockdowns. Moreover, the process of nAg uptake involves a combination of different endocytic routes. For example, both clathrin-dependent endocytosis and macropinocytosis coexisted for the uptake of nAg by human mesenchymal stem cells, as demonstrated by the decreased uptake following treatment with chlorpromazine (a clathrin inhibitor) and wortmannin (a macropinocytosis inhibitor). On the other hand, Wang and colleagues demonstrated that nAg bound to scavenger receptor on the J774A.1 cell surface and was subsequently phagocytosed by clathrin- and actin-dependent endocytosis with different inhibitors, including polyinosinic acid, chlorpromazine, nystatin and cytochalasin. ${ }^{73}$ After entering cells, nAg mainly localizes in endocytic vesicles, which ultimately merge with lysosomes, in which $\mathrm{nAg}$ can escape into cytosol and target subcellular structures. ${ }^{70,75,76}$ In our recent study with mouse erythroid progenitor cells, we verified that 


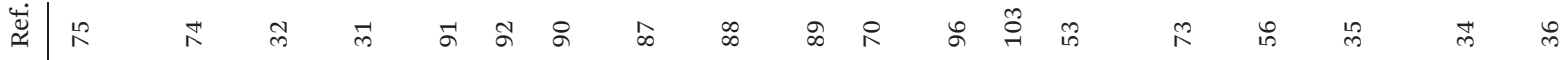

.

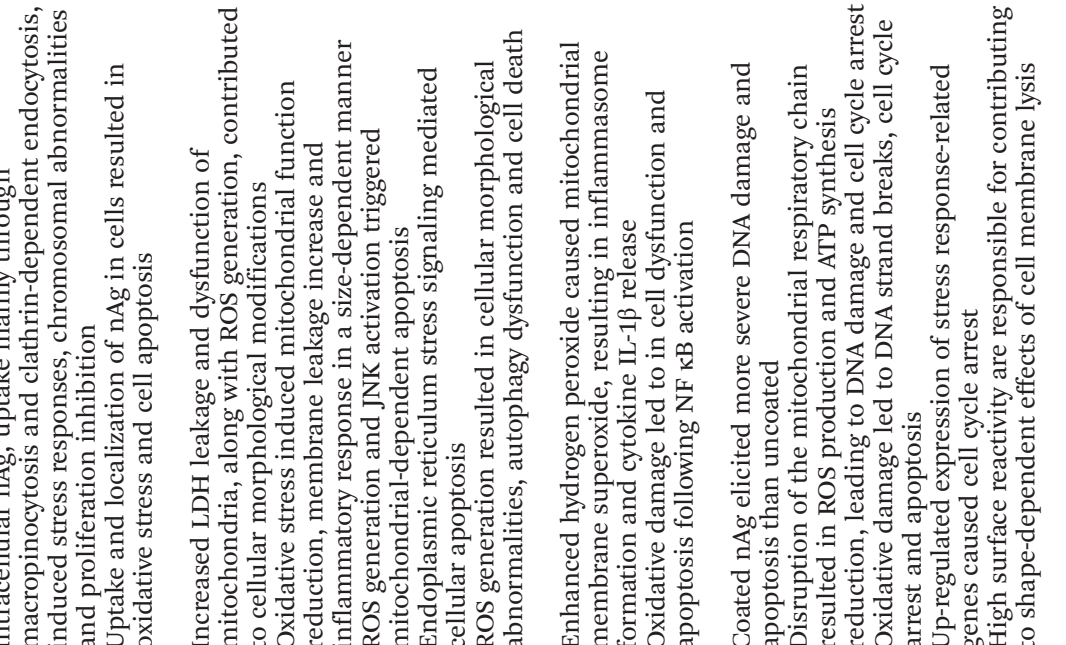

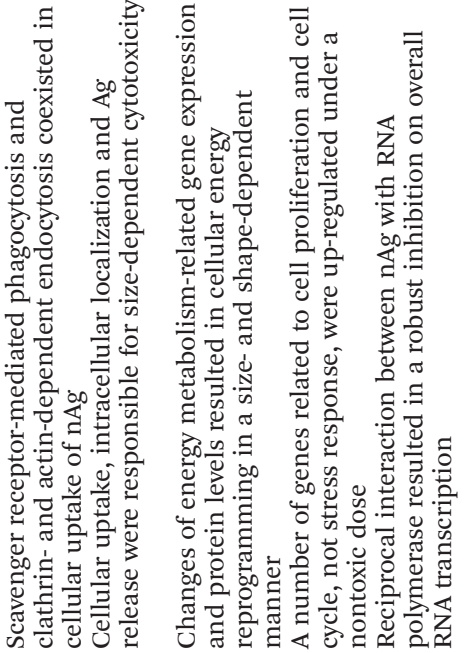

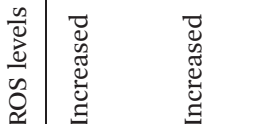

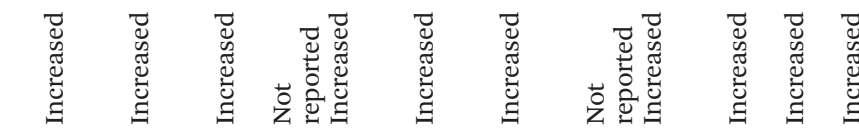

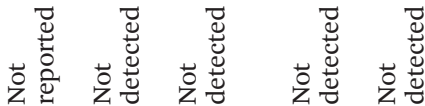

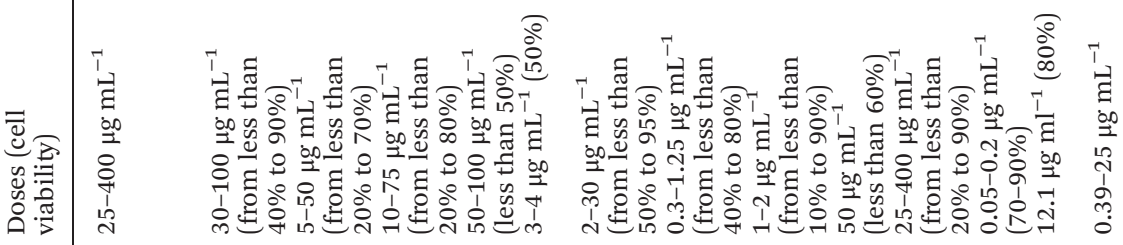

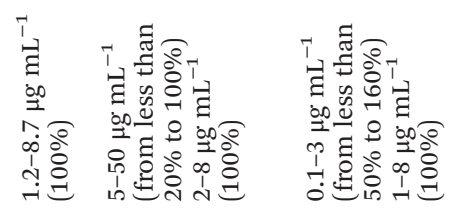
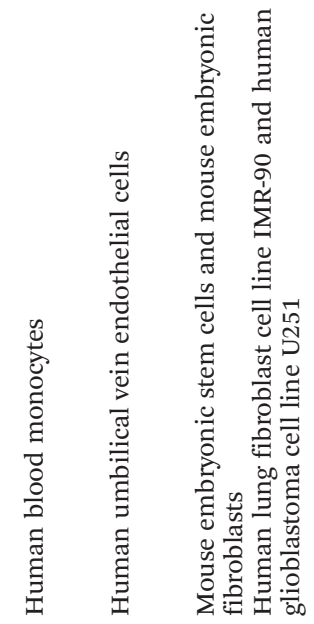

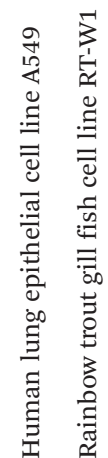
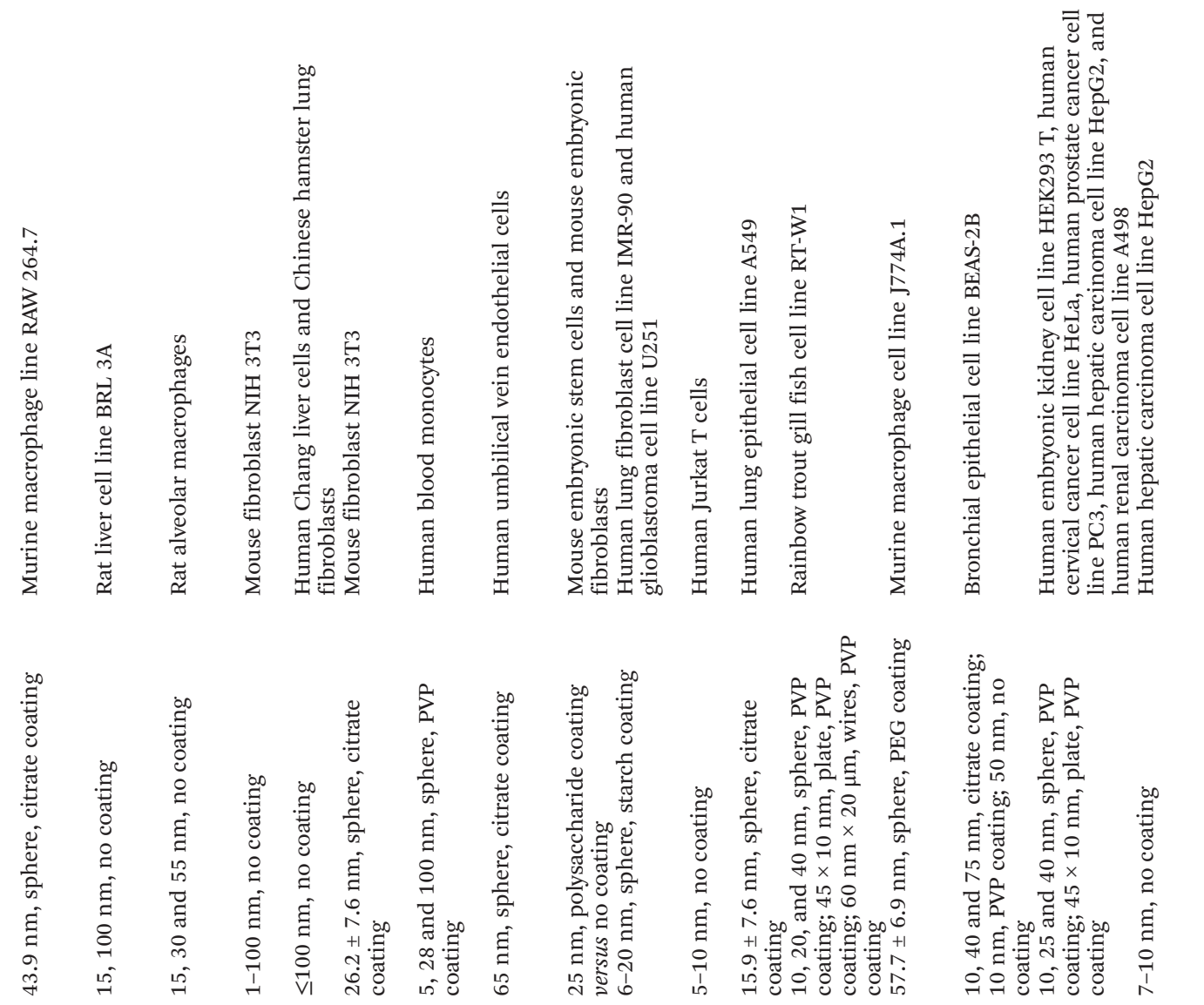

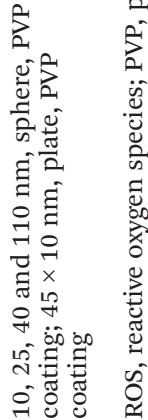




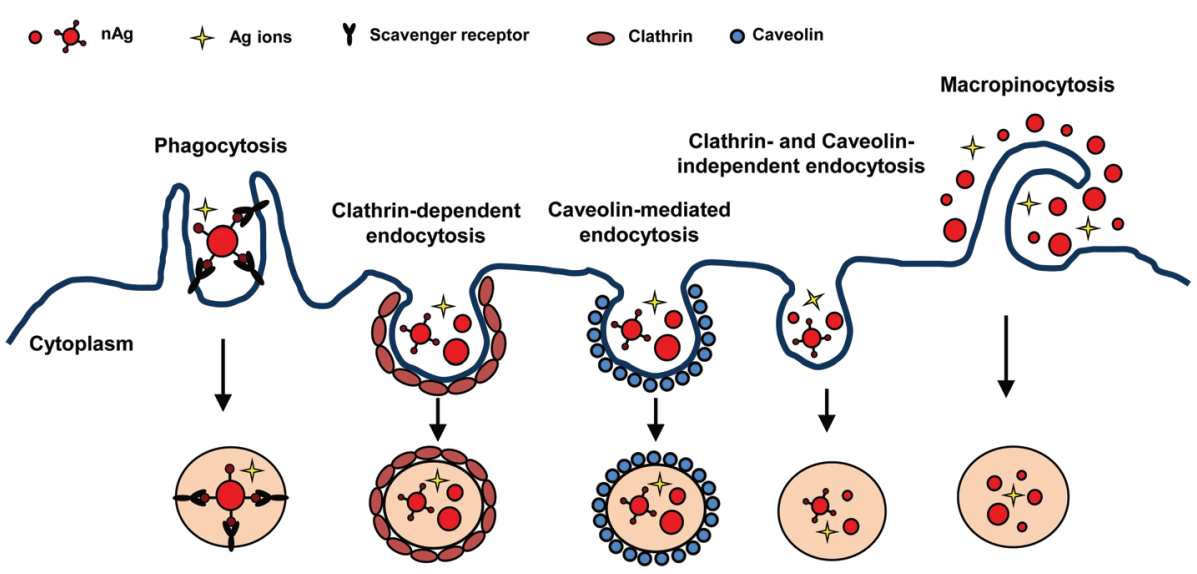

Fig. 1 Pathways for cellular uptake of $\mathrm{nAg}$. $\mathrm{nAg}$ can be internalized through different endocytosis routes.

higher percentage of $\mathrm{Ag}$ mass (75\%) was in the cytoplasmic fraction than in the nucleus $(25 \%) .^{36}$

Due to their small size, large surface area, and surface reactivity, engineered nanoparticles have the ability to bind to receptors and proteins on cell membranes. ${ }^{77}$ Interactions between nanoparticles and proteins, which will form a protein layer on the nanoparticle surface called protein corona, are operated by a number of forces, specific or nonspecific such as hydrogen bonds and interactions such as van der Waals, electrostatic, charge, steric and solvation forces. ${ }^{78,79}$ Surface ligands of nanoparticles also play an important role in determining the interactions between particles and receptors. ${ }^{78}$ Furthermore, nanoparticles in the biological system are likely to adsorb proteins onto their surfaces, causing alterations of particle properties and biological activity. ${ }^{79}$ In addition, the adsorbed proteins may undergo structural changes, function and avidity alterations, further affecting particles' interactions with receptors and other proteins. ${ }^{80}$ With regard to $\mathrm{nAg}$, one of the most commonly used engineered nanoparticles is its interactions with receptors and proteins may be related to the biophysicochemical forces, as described above. Additionally, the higher affinity of silver to thiol groups also contributes to the binding of $\mathrm{nAg}$ with sulfur-containing proteins on the membrane. ${ }^{41}$ Therefore, the intrinsic properties of nAg significantly impact its interactions with cells and determine its efficiency of cellular uptake and intracellular behavior. ${ }^{52}$ It has been demonstrated that nAg with a smaller size has a higher cellular uptake compared to a larger sized nAg. ${ }^{81}$ Moreover, the shape of nanoparticles plays an important role in deciding the efficiency of cellular uptake, including phagocytosis by macrophages. ${ }^{82}$ Spherical nAg has higher cellular uptake compared to plate-like nAg as demonstrated by a study with a fish gill epithelial cell line. ${ }^{53}$ Another study found that uncoated nAg had higher cellular uptake (10 pg Ag per cell) than PVP and citrate coated $\mathrm{nAg}$ (less than $4 \mathrm{pg} \mathrm{Ag}$ per cell) in a normal bronchial epithelial cell line, indicating that surface coating also affects the cellular uptake of $\mathrm{nAg} .{ }^{56}$ Additionally, physical and chemical transformation of $\mathrm{nAg}$ in biological settings, such as particle agglomeration and Ag ion dissolution, may considerably alter its cellular uptake and cytotoxicity. ${ }^{48,56,83}$

\subsection{ROS generation and oxidative stress: the major basis for nAg-induced cytotoxicity}

Numerous studies have suggested that the generation of ROS and resultant oxidative stress were the major mechanism responsible for $\mathrm{nAg}$-induced lethal toxicity. ${ }^{27,28,41}$ This is supported by various in vitro studies in which $\mathrm{nAg}$ exposure is at high concentrations with a significant decrease of cell viability. Deposition of $\mathrm{nAg}$ in the cytosol can disrupt mitochondrial function by inducing mechanical injury and blocking the electron transport in the mitochondrial respiratory chain, resulting in an increased ROS production. ${ }^{70}$ The Fenton-like effects in an acidic environment may be another reason for the generation of hydroxyl radicals. ${ }^{84,85}$ An additional mechanism is that $\mathrm{Ag}$ can replace ferrous ions from proteins, and subsequently induce Fenton reactions to generate ROS. ${ }^{86}$ Moreover, $\mathrm{Ag}$ can bind to glutathione (GSH, a key antioxidant), depleting GSH and increasing cellular vulnerability to ROS. $^{31,32}$ Once ROS production exceeds the level that antioxidants can neutralize, the inflammatory response and mitochondria-related cell death will follow. ${ }^{87,88}$

nAg-induced excess ROS can eventually lead to the cell death through a variety of mechanisms, including (i) lipid peroxidation and increased membrane permeability, (ii) activation of signaling cascades involving the mitochondrial pathway, (iii) abnormalities of the autophagy flux, (iv) DNA damage and cell growth arrest, as illustrated in Fig. 2. These processes seem to depend on the size and coating of the nanoparticles. A previous study by Carlson and colleagues demonstrated that $15 \mathrm{~nm} \mathrm{nAg}$ exhibited a stronger cytotoxicity to rat alveolar macrophages with more than $85 \%$ decline of cell viability, whereas $55 \mathrm{~nm} \mathrm{nAg}$ decreased cell viability by only about $15 \%$ at the same concentration $\left(50 \mu \mathrm{g} \mathrm{mL}{ }^{-1}\right) .{ }^{31}$ Another study reported that the surface chemistry of nAg greatly affects its effects on DNA stability: polysaccharide coated nAg elicited more severe DNA damage and apoptosis than uncoated nAg. ${ }^{89}$ 


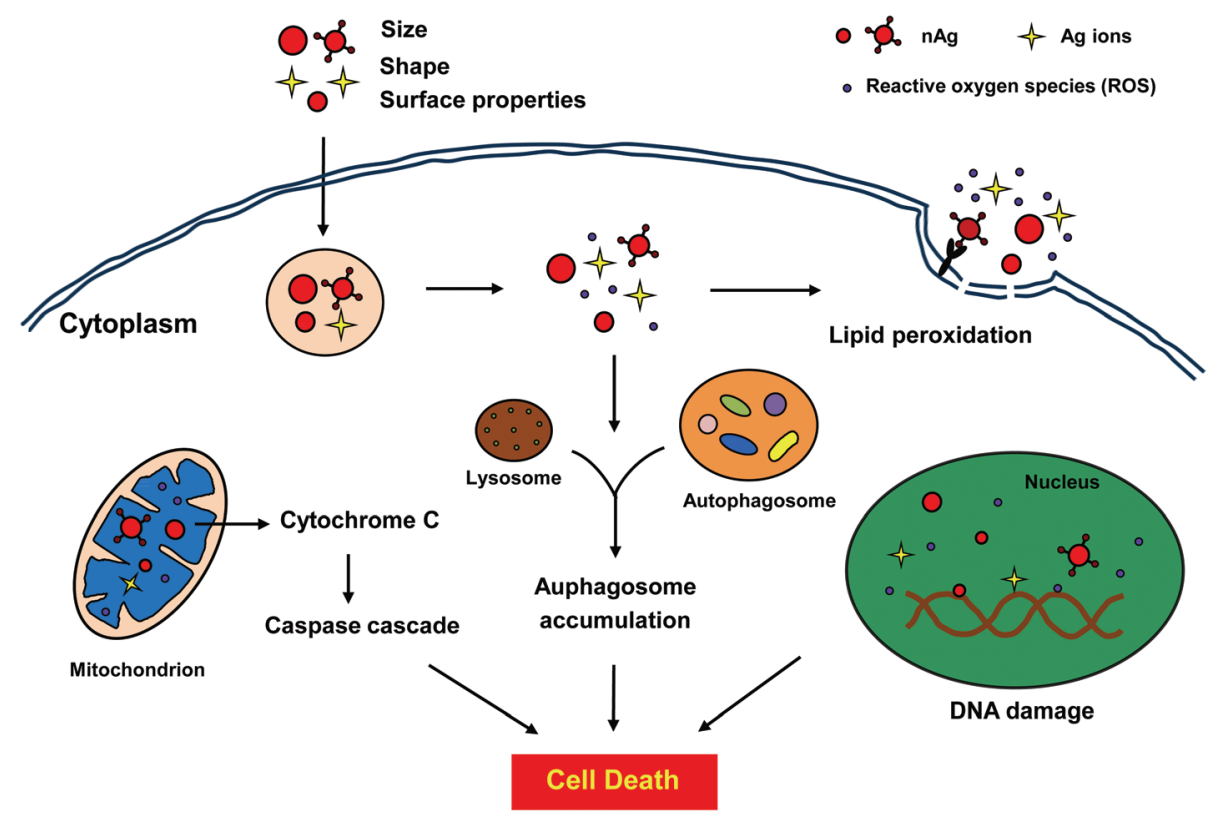

Fig. 2 Schematic overview of the cell death pathways induced by nAg. At exposure levels impacting cell viability, nAg induces excessive ROS generation that can result in lipid peroxidation on membranes, DNA damage in the nucleus, activation of a mitochondria-dependent apoptosis pathway, and disruption of autophagy flux, which ultimately leads to cell death.

nAg treatment causes different types of cell death such as apoptosis, necrosis and/or autophagy. ${ }^{41,90}$ It has been revealed that increased ROS could activate Jun N-terminal kinase (JNK) and p53, along with proapoptotic Bax translocation and mitochondrial cytochrome $\mathrm{C}$ (initiator of caspase activation) release, triggering a mitochondria-dependent pathway of apoptosis in mouse fibroblasts upon $\mathrm{nAg}$ exposure. ${ }^{91}$ In the same study, researchers found that higher concentration and longertime exposure of $\mathrm{nAg}$ lead to cell necrosis. ROS can also promote apoptosis through other cellular organelles. For example, nAg could cause apoptotic cell death through inducing endoplasmic reticulum (ER) stress. ${ }^{92}$ Moreover, recent studies indicated that autophagy, a survival mechanism deployed by cells to remove long-lived proteins and damaged organelles, might be a general cellular response to oxidative stress. ${ }^{93,94}$ With nAg treatment, excessive ROS led to the disruption of the autophagy flux, resulting in either apoptosis or autophagic cell death in mouse embryonic fibroblasts. ${ }^{90}$

It is known that ROS is the major source of spontaneous damage to DNA. The highly reactive hydroxyl radical $\left(\mathrm{OH}^{*}\right)$ can cause DNA damage to generate 8-hydroxyguanine (8-OHdG), leading to a decrease in the stability of repetitive sequences and single- and double-strand breaks. ${ }^{70,95}$ DNA damage will cause cell cycle arrest, allowing sufficient time for DNA repair. ${ }^{70,96}$ Once the damage is too extensive beyond repair, cells will undergo programmed cell death (apoptosis). ${ }^{89,97} \mathrm{~A}$ study by Eom and Choi demonstrated that increased ROS levels could activate p38 mitogen-activated protein kinase (MAPK) coupled to elevate the levels of oxidative stress, resulting in DNA strand breaks, cell cycle arrest at the G2/M phase and cell viability decline in nAg-treated T cells. ${ }^{96}$

\subsection{Molecular basis of $\mathbf{n A g}$ induced sublethal effects}

The generation of ROS and oxidative stress appears to play a primary role in nAg-induced lethal effects; however, they are not the only pathway by which nAg exert cytotoxicity. For instance, Gliga and colleagues demonstrated that nAg showed profound cytotoxicity in human lung cells independent of intracellular ROS production. ${ }^{56}$ Our recent studies also revealed that nAg-mediated inhibition of oxidative phosphorylation and interruption of gene transcription are irrespective of ROS generation. ${ }^{35,36}$ In the following subsection, we will show the molecular basis for nAg-mediated detrimental effects at concentrations where excessive ROS are not detected and no significant decline of cell viability are observed.

3.3.1. Disruption of energy homeostasis. Mitochondria represent the most important organelle in-charge of energy production and maintaining energy homeostasis in mammalian cells. ${ }^{98}$ It seems that nAg at lethal doses tends to disturb cellular redox homeostasis, induce excess ROS production, and then increase mitochondrial membrane permeability, which uncouples the oxidative phosphorylation from the respiratory chain. ${ }^{32,99,100}$ Given that ATP is essential for numerous cellular processes, including proteins and DNA damage repair, the interruption of ATP synthesis will disturb DNA repair, leading to a cell cycle arrest and apoptosis. ${ }^{70,101}$ In contrast, $\mathrm{nAg}$ at sublethal doses could interfere with cellular energy balance, including the activity of respiratory chain complexes in mitochondria, and/or alter energy metabolism-related gene expression and protein levels, without ROS generation or cell death. ${ }^{35,102}$ Our own recent study demonstrated that sublethal nAg could reduce ATP synthesis and resulted in energy 


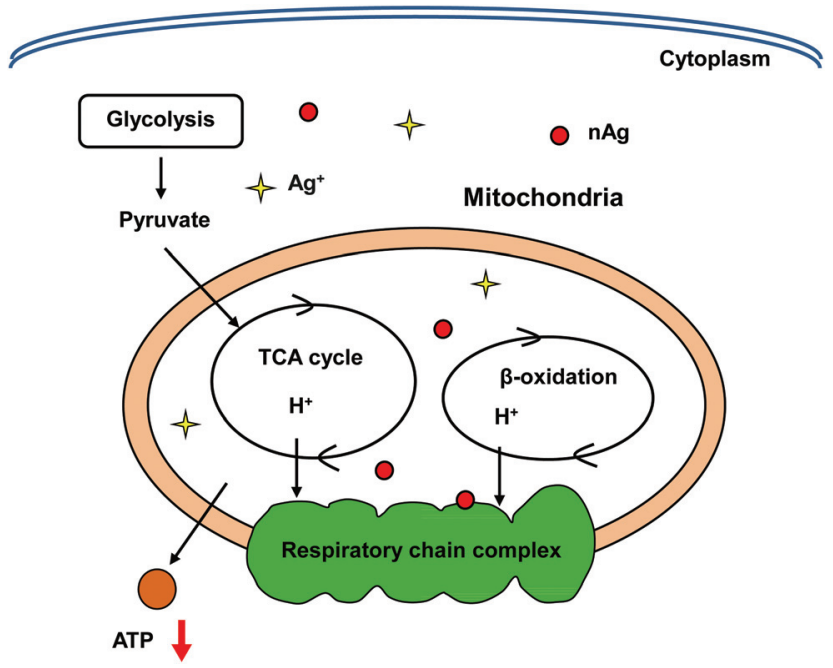

Fig. $3 \mathrm{nAg}$ induces reprograming of energy metabolism at sublethal doses. The schematic diagram reveals that $\mathrm{nAg}$ can inhibit a key regulator of cellular energy metabolism, PGC- $\alpha$ expression as well as many energy metabolism-related proteins. These changes result in a decrease in oxidative phosphorylation and compensatory increase of glycolysis. This is a reproduction from our research group with modifications. ${ }^{35}$

metabolism reprogramming, as depicted in Fig. $3 .^{35} \mathrm{We}$ treated a panel of human tumor and nontumor cells with nAg at low concentrations $\left(2-8 \mu \mathrm{g} \mathrm{mL}^{-1}\right)$ and found that intracellular nAg could reduce the concentration of peroxisome proliferator-activated receptor $\gamma$ coactivator $1 \alpha$ (PGC-1 $\alpha$, a central regulator of mitochondrial energy transduction) and pyruvate dehydrogenase ( $\mathrm{PDH}$, a key enzyme for oxidative phosphorylation initiation). These nAg-induced alternations at crucial protein levels forced cellular energy homeostasis to switch from oxidative phosphorylation-based aerobic metabolism to anaerobic glycolysis to satisfy basal energy demand for cell survival. In this study, spherical nAg with smaller size presented greater alterations on cellular energy metabolism compared to larger size nanospheres and nanoplates. Moreover, non-tumor HEK293 T cells showed higher susceptibility to switch on glycolysis than tumor cells for a greater respiration rate in nontumor cells. ${ }^{35}$

3.3.2. Alteration of proliferation-related genes. Recent studies indicated that both lethal and sublethal $\mathrm{nAg}$ could alter gene expression profiles once exposed to mammalian cells. Coupled with increased ROS and decreased cell viability, $\mathrm{nAg}$ tends to up-regulate gene expression levels related to stress response but down-regulate gene expression levels related to cell cycle execution. ${ }^{103}$ Inversely, it appears that nAg is more inclined to increase the expression levels of proliferation-related genes in exposed cells at concentrations without reducing cell viability. In a study by Kawata and colleagues, a number of up-regulated genes (122 of total 236) were involved in cell proliferation and cell cycle progression, such as $\mathrm{M}$ phase, microtubule-based process, DNA biosynthesis and intracellular transport, upon $1 \mu \mathrm{g} \mathrm{mL} \mathrm{m}^{-1} \mathrm{nAg}$ with $100 \%$ cell via- bility. ${ }^{34}$ Oxidative stress-related genes were not induced at a similarly low concentration of nAg. The elevated genes implicated in the cell cycle resulted in an increase in the cell number $>20 \%$ upon the addition of $\mathrm{nAg}$ at doses of less than $0.5 \mu \mathrm{g} \mathrm{mL} \mathrm{m}^{-1}$, indicating that sublethal $\mathrm{nAg}$ potentially promotes cell proliferation.

3.3.3. Inhibition of RNA transcription. Nanoparticles can impair the cellular transcription machinery and interrupt genetic integrity, which is different from ROS-induced DNA point mutations or/and single- or double-strand breaks. ${ }^{104}$ Although lethal nAg can induce DNA damage via ROS production, our current study demonstrated that low concentrations of $\mathrm{nAg}$ could interrupt the transcription machinery and reduce overall RNA synthesis through directly binding to RNA polymerase, as illustrated in Fig. $4 .^{36}$ Mouse erythroid progenitor (MEL) cells were exposed to PVP-coated nAg at concentrations (1-8 $\mu \mathrm{g} \mathrm{mL} \mathrm{m}^{-1}$ ) without provoking ROS and without a decline in cell viability. After exposure for $48 \mathrm{~h}$, cellular total RNAs, including 18S rRNA and 28S rRNA, were substantially inhibited, as characterized by a large reduction in the intensity of nascent RNAs through autoradiography. The acellular pulldown assay of nAg with RNA polymerase showed that nAg could precipitate RNA polymerase. Furthermore, when we used an anti-RNA polymerase II antibody to precipitate RNA polymerase and an ICP-MS assay to detect Ag content in the immunoprecipitates, Ag was present only in the co-immunoprecipitated complexes extracted from nAg-treated cells in a dose-dependent manner. These results proved a direct reciprocal interaction between $\mathrm{nAg}$ and RNA polymerase, which interrupted the transcription machinery and led to a robust inhibition on overall RNA transcription. The interactions of nanoparticles with polymerase, similar to that of nanoparticles with proteins on the membrane, may be involved in various physicochemical forces and sulfur-containing amino acids, which needs further investigation in future studies.

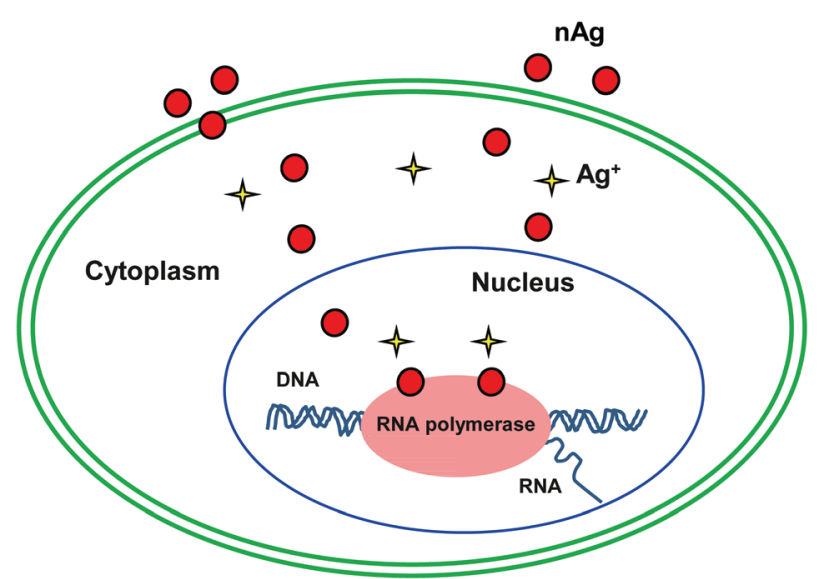

Fig. 4 A schematic indicating that nAg binds to RNA polymerase and inhibits RNA transcription in erythroid progenitor cells, leading to overall repression of RNA synthesis. This is a reproduction from our research group with modifications. ${ }^{36}$ 
nAg-induced inhibition on RNA transcription in erythroid cells in vivo was confirmed using fetal liver at E14.5, an optimal model for embryonic definitive erythropoiesis, following intraperitoneal administration of $22 \mu \mathrm{g} \mathrm{kg}{ }^{-1} \mathrm{nAg}$ in parental mice for 4 weeks. ${ }^{36}$ The microarray analysis showed that 264 genes of a total of 301 differentially expressed genes were repressed in fetal liver cells of embryos from nAg-treated mice. A large array of these down-regulated genes was associated with the regulation of erythropoiesis in erythroid cells. The significant inhibition of nAg on vital genes and overall RNA transcription, different from ROS-induced placental damage, resulted in anemia and developmental retardation in mouse embryos.

\subsection{Contribution of $\mathrm{Ag}$ ion toxicity and particle effects}

Previous studies have demonstrated that $\mathrm{nAg}$ has the potential to release $\mathrm{Ag}$ ions in biological settings. ${ }^{83,105}$ The release rate is not dependent on nAg's exposure levels, and the release of $\mathrm{Ag}$ ions from nAg can happen at both lethal and sublethal concentrations. Ag ions are generally considered the main mechanism of nAg-induced toxicity. Ag ions have the ability to bind to sulfur-containing proteins in the plasma membrane and inside cells, resulting in the disruption of membrane integrity, dysfunctions of proteins and formation of ROS. ${ }^{41,106}$ Interaction with DNA base pairs and induction of DNA damage are also mechanistic responses in cells exposed to Ag ions. ${ }^{41}$ The role of $\mathrm{Ag}$ ions is further supported by findings showing that no toxicity was observed when $\mathrm{Ag}$ ions were complexed by their ligands.

However, nAg-induced cytotoxicity is also reported to depend on $\mathrm{Ag}$ nanoparticles. ${ }^{35,36,56}$ These studies suggested that the nanoparticle form of Ag could provide particle specific effects associated with impacting toxicity in addition to Ag dissolution. In other words, both nano-sized particles of $\mathrm{Ag}$ and ionic $\mathrm{Ag}$ could be involved in $\mathrm{nAg}$-mediated detrimental effects. It has been recently considered that nAg acts as a Trojan horse (a vehicle or carrier) to transport ions/particles into cells, promoting the penetrability and bioavailability of particles and $\mathrm{Ag}$ ions in cells and organisms. ${ }^{54-56}$ Although whether and to what extent nAg exists in the form of nanoparticles is still ambiguous, recent studies by our group and the other groups demonstrated that more than $80 \%$ of $\mathrm{Ag}$ presented in the form of nanoparticles via the cloud point extraction (CPE) method, indicating that particles might be the main form of $\mathrm{nAg}$ inside cells. ${ }^{36,107}$ On the other hand, $\mathrm{nAg}$ particles could be more active during their interactions with biological molecules. ${ }^{5,11}$ The smaller nanoparticles have larger surface area, more binding sites, and thus higher $\mathrm{Ag}$ ion release and ROS production, leading to more harmful effects than the bulk particles. Furthermore, due to higher surface reactivity, Ag nanoplates were more toxic than Ag nanospheres and $\mathrm{Ag}$ nanowires to fish gill epithelial cells, despite their lower rates of dissolution and bioavailability. ${ }^{53}$ Additionally, surface coating can reduce dissolution rates of $\mathrm{nAg}$ and/or bind to $\mathrm{Ag}$ ions after dissolution, consequently decreasing the toxicity. ${ }^{105}$

In summary, the physicochemical properties of $\mathrm{nAg}$ affect its cellular availability, interaction activity, $\mathrm{Ag}$ ion release and thus its consequent cytotoxicity, indicating similarities in the response of cells to lethal and sublethal doses of nAg. However, there are still pronounced differences. The direct indication of lethal cytotoxicity of $\mathrm{nAg}$ is cell death, which masks other predominant mechanisms underlying nAginduced biological effects. Increased ROS generation and oxidative stress are the major routes through which high-dose $\mathrm{nAg}$ induces overt toxic effects. Under sublethal doses, nAg interferes with biomolecules in a more subtle manner with minimal ROS production and little impact on cell viability. As discussed above, sublethal nAg can disturb cellular energy homeostasis not through ROS-mediated depolarization of mitochondrial membrane potential, but mainly through indirect alternations of energy supply-related mRNA and protein levels. Moreover, sublethal doses of $\mathrm{nAg}$ can interfere with more biological processes, including cell proliferation, RNA transcription and erythropoiesis and be devoid of significant stress responses. The similarities (i.e. common mechanisms) and differences (i.e. novel mechanisms) between lethal toxicity and sublethal toxicity of nAg are summarized in Table 3.

Table 3 Similarities and differences in the response of cells to $\mathrm{nAg}$ at lethal and sublethal concentrations

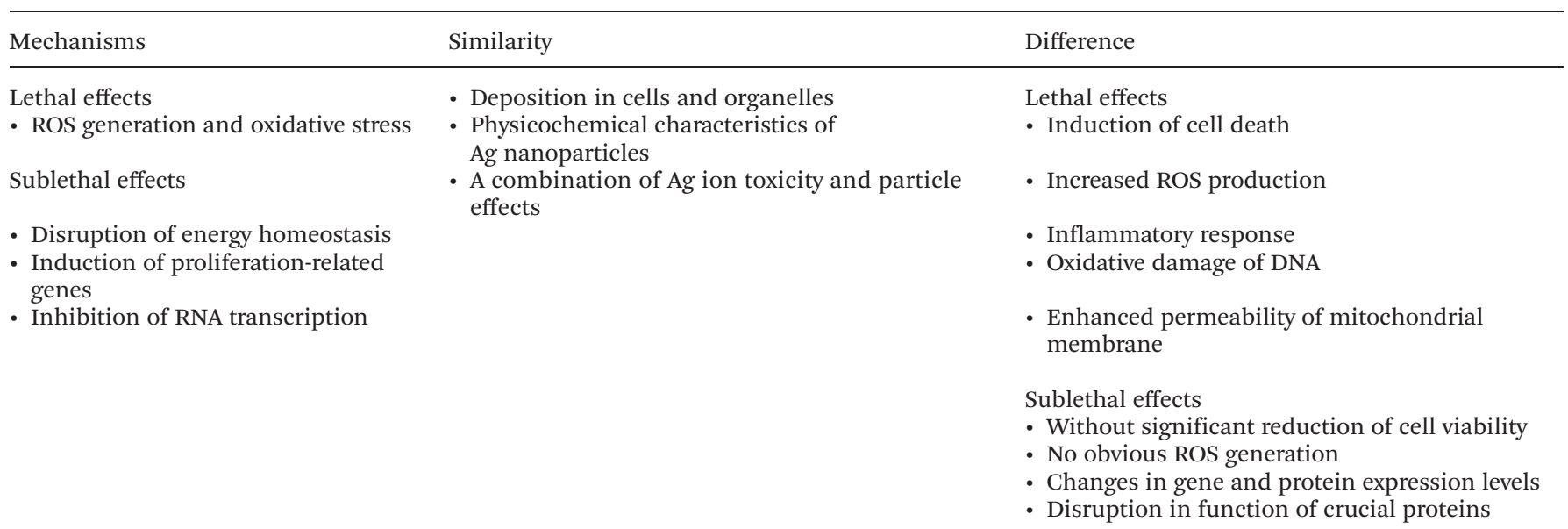




\section{Conclusions and perspectives}

In this review, we emphasize the importance of sublethal effects of nAg at low exposure levels to better assess health hazards of $\mathrm{nAg}$ under environmentally relevant conditions. Analogous to a variety of environmental pollutants, nAg exhibits chronic impairments (i.e., sublethal effects) that are more relevant to environmental conditions but have long been under-researched. Based on in vitro studies, nAg can perturb cellular pathways at the molecular level under sublethal doses without eliciting overt cytotoxicity. Enhancement of aerobic glycolysis, induction of cell proliferation-related genes, and inhibition of RNA polymerase-mediated transcription by $\mathrm{nAg}$ suggest a distinct effect of $\mathrm{nAg}$ at sublethal doses.

Although the sublethal doses are possibly still higher than actual human exposure levels that are still unclear to date, we can claim that studying the chronic effects of nAg at low (sublethal) doses is a necessary step in the right direction. However, there have been very limited investigations related to sublethal effects from exposure to $\mathrm{nAg}$. To assess these effects of $\mathrm{nAg}$, we need to perform dose-response studies and determine the sublethal doses for cell models through different methods such as morphological observation, cell counting, MTT and Alarmar Blue assays. Then, we should survey its subcellular localization and effects on cellular functions and search for appropriate indicators of sublethal toxicity such as alterations of gene transcription and biochemical markers specific to cell functions. Thereafter, animal exposure studies should be carried out to validate the in vitro findings. Moreover, due to transformation of $\mathrm{nAg}$ in biological media, researchers should use various nAg with different physicochemical properties in order to verify how the alternation of basic properties impact its bioavailability, cellular uptake and subcellular localization and subsequent biological effects. The improved understanding of nAg's sublethal effects will assist in elucidating their potential adverse effects on human health.

\section{Competing interests}

No potential conflicts of interest were disclosed from the authors.

\section{Impact statement}

Analogous to the health impacts induced by environmental pollutants, the chronic toxicity of $\mathrm{nAg}$ at low doses is possibly different from the acute toxicity at high doses. Previous findings indicate that sublethal nAg exposure could also cause significant adverse effects in cells and animals. Therefore, to evaluate the potential hazards of $\mathrm{nAg}$, it is desirable to examine not only acute lethal effects but also chronic sublethal effects. Further understanding of nAg-induced detrimental effects at low concentrations will be helpful in investigating the health effects of $\mathrm{nAg}$ under environmentally relevant conditions.

\section{Acknowledgements}

This work was supported by a grant under the national "973" program (grant number: 2014CB932000), grants from the National Natural Science Foundation of China (grant numbers: 21407172, 21377159, 21177151, 21207152, 21425731), the Strategic Priority Research Program of the Chinese Academy of Sciences (grant no. XDB14000000), and the International Postdoctoral Exchange Fellowship Program (the approval document number: no. 57 Document of OCPC, 2013). TX was supported by National Institute of Environmental Health Sciences, U19ES019528, R01 ES016746, and the National Science Foundation and the Environmental Protection Agency under Cooperative Agreement Number DBI 0830117 and 1266377.

\section{References}

1 Z. Chen, S. M. Tabakman, A. P. Goodwin, M. G. Kattah, D. Daranciang, X. R. Wang, G. Y. Zhang, X. L. Li, Z. Liu, P. J. Utz, K. L. Jiang, S. S. Fan and H. J. Dai, Nat. Biotechnol., 2008, 26, 1285-1292.

2 X. Qian, X. H. Peng, D. O. Ansari, Q. Yin-Goen, G. Z. Chen, D. M. Shin, L. Yang, A. N. Young, M. D. Wang and S. Nie, Nat. Biotechnol., 2008, 26, 83-90.

3 X. Michalet, F. F. Pinaud, L. A. Bentolila, J. M. Tsay, S. Doose, J. J. Li, G. Sundaresan, A. M. Wu, S. S. Gambhir and S. Weiss, Science, 2005, 307, 538-544.

4 K. Chaloupka, Y. Malam and A. M. Seifalian, Trends Biotechnol., 2010, 28, 580-588.

5 S. W. P. Wijnhoven, W. J. G. M. Peijnenburg, C. A. Herberts, W. I. Hagens, A. G. Oomen, E. H. W. Heugens, B. Roszek, J. Bisschops, I. Gosens, D. Van de Meent, S. Dekkers, W. H. De Jong, M. Van Zijverden, A. J. A. M. Sips and R. E. Geertsma, Nanotoxicology, 2009, 3, 109-U178.

6 T. Faunce and A. Watal, Nanomedicine, 2010, 5, 617-632.

7 N. Seltenrich, Environ. Health Perspect., 2013, 121, A220A225.

8 J. K. Schluesener and H. J. Schluesener, Arch. Toxicol., 2013, 87, 569-576.

9 http://www.nanotechproject.org/inventories/consumer/ analysis_draft/.

10 R. D. Glover, J. M. Miller and J. E. Hutchison, ACS Nano, 2011, 5, 8950-8957.

11 X. Chen and H. J. Schluesener, Toxicol. Lett., 2008, 176, 1-12.

12 G. Oberdorster, E. Oberdorster and J. Oberdorster, Environ. Health Perspect., 2005, 113, 823-839.

13 X. Wang, Z. X. Ji, C. H. Chang, H. Y. Zhang, M. Y. Wang, Y. P. Liao, S. J. Lin, H. Meng, R. B. Li, B. B. Sun, L. V. Winkle, K. E. Pinkerton, J. I. Zink, T. Xia and A. E. Nel, Small, 2014, 10, 385-398.

14 L. K. Limbach, P. Wick, P. Manser, R. N. Grass, A. Bruinink and W. J. Stark, Environ. Sci. Technol., 2007, 41, 4158-4163. 
15 Y. F. Li and C. Chen, Small, 2011, 7, 2965-2980.

16 M. F. Hughes, B. D. Beck, Y. Chen, A. S. Lewis and D. J. Thomas, Toxicol. Sci., 2011, 123, 305-332.

17 F. Thevenod and W. K. Lee, Met. Ions Life Sci., 2013, 11, 415-490.

18 Y. S. Hong, Y. M. Kim and K. E. Lee, J. Prev. Med. Pub. Health, 2012, 45, 353-363.

19 L. Benbrahim-Tallaa and M. P. Waalkes, Environ. Health Perspect., 2008, 116, 158-164.

20 L. Jarup and A. Akesson, Toxicol. Appl. Pharm., 2009, 238, 201-208.

21 P. Grandjean, H. Satoh, K. Murata and K. Eto, Environ. Health Perspect., 2010, 118, 1137-1145.

22 R. Ruckerl, A. Schneider, S. Breitner, J. Cyrys and A. Peters, Inhal. Toxicol., 2011, 23, 555-592.

23 R. D. Brook, S. Rajagopalan, C. A. Pope, 3rd, J. R. Brook, A. Bhatnagar, A. V. Diez-Roux, F. Holguin, Y. Hong, R. V. Luepker, M. A. Mittleman, A. Peters, D. Siscovick, S. C. Smith Jr., L. Whitsel and J. D. Kaufman, Circulation, 2010, 121, 2331-2378.

24 S. A. Weichenthal, K. Godri-Pollitt and P. J. Villeneuve, Environ. Health, 2013, 12, 40.

25 Y. L. Jia, D. Stone, W. T. Wang, J. Schrlau, S. Tao and S. L. M. Simonich, Environ. Health Perspect., 2011, 119, 815-820.

26 S. Eckhardt, P. S. Brunetto, J. Gagnon, M. Priebe, B. Giese and K. M. Fromm, Chem. Rev., 2013, 113, 4708-4754.

27 H. J. Johnston, G. Hutchison, F. M. Christensen, S. Peters, S. Hankin and V. Stone, Crit. Rev. Toxicol., 2010, 40, 328346.

28 M. Ahamed, M. S. Alsalhi and M. K. Siddiqui, Clin. Chim. Acta, 2010, 411, 1841-1848.

29 S. M. Mirsattari, R. R. Hammond, M. D. Sharpe, F. Y. Leung and G. B. Young, Neurology, 2004, 62, 1408-1410.

30 D. Schmaehl and D. Steinhoff, Z. Krebsforsch., 1960, 63, 586-591.

31 C. Carlson, S. M. Hussain, A. M. Schrand, L. K. BraydichStolle, K. L. Hess, R. L. Jones and J. J. Schlager, J. Phys. Chem. B, 2008, 112, 13608-13619.

32 S. M. Hussain, K. L. Hess, J. M. Gearhart, K. T. Geiss and J. J. Schlager, Toxicol. in Vitro, 2005, 19, 975-983.

33 L. Braydich-Stolle, S. Hussain, J. J. Schlager and M. C. Hofmann, Toxicol. Sci., 2005, 88, 412-419.

34 K. Kawata, M. Osawa and S. Okabe, Environ. Sci. Technol., 2009, 43, 6046-6051.

35 Y. Chen, Z. Wang, M. Xu, X. Wang, R. Liu, Q. Liu, Z. Zhang, T. Xia, J. Zhao, G. Jiang, Y. Xu and S. Liu, ACS Nano, 2014, 8, 5813-5825.

36 Z. Wang, S. J. Liu, J. Ma, G. B. Qu, X. Y. Wang, S. J. Yu, J. Y. He, J. F. Liu, T. Xia and G. B. Jiang, ACS Nano, 2013, 7, 4171-4186.

37 S. N. Luoma, Project on Emerging Nanotechnologies, Woodrow Wilson International Center for Scholars, Washington, DC, 2008.

38 Agency for Toxic Substances and Disease Registry Public Health Statement, Toxicological Profile for Silver, U.S.
Department of Health and Human Services, Public Health Service, Atlanta, GA, 1990.

39 F. Gottschalk, T. Sonderer, R. W. Scholz and B. Nowack, Environ. Sci. Technol., 2009, 43, 9216-9222.

40 B. P. Colman, C. L. Arnaout, S. Anciaux, C. K. Gunsch, M. F. Hochella, Jr., B. Kim, G. V. Lowry, B. M. McGill, B. C. Reinsch, C. J. Richardson, J. M. Unrine, J. P. Wright, L. Yin and E. S. Bernhardt, PLoS One, 2013, 8, e57189.

41 C. Volker, M. Oetken and J. Oehlmann, Rev. Environ. Contam. Toxicol., 2013, 223, 81-106.

42 J. R. Morones, J. L. Elechiguerra, A. Camacho, K. Holt, J. B. Kouri, J. T. Ramirez and M. J. Yacaman, Nanotechnology, 2005, 16, 2346-2353.

43 W. R. Li, X. B. Xie, Q. S. Shi, H. Y. Zeng, Y. S. Ou-Yang and Y. B. Chen, Appl. Microbiol. Biotechnol, 2010, 85, 11151122.

44 A. B. Landsdown and A. Williams, J. Wound Care, 2007, 16, 15-19.

45 I. Chopra, J. Antimicrob. Chemother., 2007, 59, 587-590.

46 D. W. Brett, Ostomy Wound Manage., 2006, 52, 34-41.

47 Z. M. Xiu, Q. B. Zhang, H. L. Puppala, V. L. Colvin and P. J. Alvarez, Nano Lett., 2012, 12, 4271-4275.

48 K. J. Lee, P. D. Nallathamby, L. M. Browning, C. J. Osgood and X. H. Xu, ACS Nano, 2007, 1, 133-143.

49 S. A. Love, M. A. Maurer-Jones, J. W. Thompson, Y. S. Lin and C. L. Haynes, Annu. Rev. Anal. Chem., 2012, 5, 181-205.

50 A. G. Skirtach, A. A. Antipov, D. G. Shchukin and G. B. Sukhorukov, Langmuir, 2004, 20, 6988-6992.

51 A. G. Skirtach, A. Munoz Javier, O. Kreft, K. Kohler, A. Piera Alberola, H. Mohwald, W. J. Parak and G. B. Sukhorukov, Angew. Chem., Int. Ed., 2006, 45, 46124617.

52 A. Albanese, P. S. Tang and W. C. Chan, Annu. Rev. Biomed. Eng., 2012, 14, 1-16.

53 S. George, S. J. Lin, Z. X. Jo, C. R. Thomas, L. J. Li, M. Mecklenburg, H. Meng, X. Wang, H. Y. Zhang, T. Xia, J. N. Hohman, S. Lin, J. I. Zink, P. S. Weiss and A. E. Nel, ACS Nano, 2012, 6, 3745-3759.

54 E. J. Park, J. Yi, Y. Kim, K. Choi and K. Park, Toxicol In Vitro, 2010, 24, 872-878.

55 X. Jiang, T. Miclaus, L. Wang, R. Foldbjerg, D. S. Sutherland, H. Autrup, C. Chen and C. Beer, Nanotoxicology, 2015, 9, 181-189.

56 A. R. Gliga, S. Skoglund, I. O. Wallinder, B. Fadeel and H. L. Karlsson, Part. Fibre Toxicol., 2014, 11, 11.

57 E. Sudmann, H. Vik, M. Rait, K. Todnem, K. J. Andersen, K. Julsham, O. Flesland and J. Rungby, Med. Prog. Technol., 1994, 20, 179-184.

58 G. Ellender and K. N. Ham, Br. J. Exp. Pathol., 1989, 70, 21-39.

59 M. E. Samberg, S. J. Oldenburg and N. A. MonteiroRiviere, Environ. Health Perspect., 2010, 118, 407-413.

60 J. H. Sung, J. H. Ji, J. U. Yoon, D. S. Kim, M. Y. Song, J. Jeong, B. S. Han, J. H. Han, Y. H. Chung, J. Kim, T. S. Kim, H. K. Chang, E. J. Lee, J. H. Lee and I. J. Yu, Inhal. Toxicol., 2008, 20, 567-574. 
61 K. S. Song, J. H. Sung, J. H. Ji, J. H. Lee, J. S. Lee, H. R. Ryu, J. K. Lee, Y. H. Chung, H. M. Park, B. S. Shin, H. K. Chang, B. Kelman and I. J. Yu, Nanotoxicology, 2013, 7, 169-180.

62 Y. S. Kim, J. S. Kim, H. S. Cho, D. S. Rha, J. M. Kim, J. D. Park, B. S. Choi, R. Lim, H. K. Chang, Y. H. Chung, I. H. Kwon, J. Jeong, B. S. Han and I. J. Yu, Inhal. Toxicol., 2008, 20, 575-583.

63 N. Hadrup and H. R. Lam, Regul. Toxicol. Pharmacol., 2014, 68, 1-7.

64 J. H. Lee, K. Ahn, S. M. Kim, K. S. Jeon, J. S. Lee and I. J. Yu, J. Nanopart. Res., 2012, 14, 1134-1143.

65 H. Y. Lee, Y. J. Choi, E. J. Jung, H. Q. Yin, J. T. Kwon, J. E. Kim, H. T. Im, M. H. Cho, J. H. Kim, H. Y. Kim and B. H. Lee, J. Nanopart. Res., 2010, 12, 1567-1578.

66 J. L. Tang, L. Xiong, S. Wang, J. Y. Wang, L. Liu, J. A. Li, Z. Y. Wan and T. F. Xi, Appl. Surf. Sci., 2008, 255, 502-504.

67 J. Tang, L. Xiong, S. Wang, J. Wang, L. Liu, J. Li, F. Yuan and T. Xi, J. Nanosci. Nanotechnol., 2009, 9, 4924-4932.

68 Y. Lee, J. Choi, P. Kim, K. Choi, S. Kim, W. Shon and K. Park, Toxicol. Res., 2012, 28, 139-141.

69 Z. Wang, G. B. Qu, L. N. Su, L. Wang, Z. Z. Yang, J. Q. Jiang, S. J. Liu and G. B. Jiang, Curr. Pharm. Des., 2013, 19, 6691-6697.

70 P. V. AshaRani, G. Low Kah Mun, M. P. Hande and S. Valiyaveettil, ACS Nano, 2009, 3, 279-290.

71 S. Kim and D. Y. Ryu, J. Appl. Toxicol., 2013, 33, 78-89.

72 T. Xia, M. Kovochich, M. Liong, J. I. Zink and A. E. Nel, ACS Nano, 2008, 2, 85-96.

73 H. Wang, L. Wu and B. M. Reinhard, ACS Nano, 2012, 6, 7122-7132.

74 R. P. Singh and P. Ramarao, Toxicol. Lett., 2012, 213, 249-259.

75 P. V. Asharani, M. P. Hande and S. Valiyaveettil, BMC Cell Biol., 2009, 10, 65.

76 C. Greulich, J. Diendorf, T. Simon, G. Eggeler, M. Epple and M. Koller, Acta Biomater., 2011, 7, 347-354.

77 A. Nel, T. Xia, L. Madler and N. Li, Science, 2006, 311, 622627.

78 A. E. Nel, L. Madler, D. Velegol, T. Xia, E. M. V. Hoek, P. Somasundaran, F. Klaessig, V. Castranova and M. Thompson, Nat. Mater., 2009, 8, 543-557.

79 S. R. Saptarshi, A. Duschl and A. L. Lopata, J. Nanobiotechnol., 2013, 11, 26.

80 D. M. Brown, C. Dickson, P. Duncan, F. Al-Attili and V. Stone, Nanotechnology, 2010, 21, 215104.

81 W. Liu, Y. Wu, C. Wang, H. C. Li, T. Wang, C. Y. Liao, L. Cui, Q. F. Zhou, B. Yan and G. B. Jiang, Nanotoxicology, 2010, 4, 319-330.

82 J. A. Champion and S. Mitragotri, Proc. Natl. Acad. Sci. U. S. A., 2006, 103, 4930-4934.

83 A. Pratsinis, P. Hervella, J. C. Leroux, S. E. Pratsinis and G. A. Sotiriou, Small, 2013, 9, 2576-2584.

84 W. He, Y. T. Zhou, W. G. Wamer, M. D. Boudreau and J. J. Yin, Biomaterials, 2012, 33, 7547-7555.
85 D. He, C. J. Miller and T. D. Waite, J. Catal., 2014, 317, 198-205.

86 O. Gordon, T. Vig Slenters, P. S. Brunetto, A. E. Villaruz, D. E. Sturdevant, M. Otto, R. Landmann and K. M. Fromm, Antimicrob. Agents Chemother., 2010, 54, 4208-4218.

87 E. J. Yang, S. Kim, J. S. Kim and I. H. Choi, Biomaterials, 2012, 33, 6858-6867.

88 J. Shi, X. Sun, Y. Lin, X. Zou, Z. Li, Y. Liao, M. Du and H. Zhang, Biomaterials, 2014, 35, 6657-6666.

89 M. Ahamed, M. Karns, M. Goodson, J. Rowe, S. M. Hussain, J. J. Schlager and Y. Hong, Toxicol. Appl. Pharmacol., 2008, 233, 404-410.

90 Y. H. Lee, F. Y. Cheng, H. W. Chiu, J. C. Tsai, C. Y. Fang, C. W. Chen and Y. J. Wang, Biomaterials, 2014, 35, 47064715.

91 Y. H. Hsin, C. F. Chena, S. Huang, T. S. Shih, P. S. Lai and P. J. Chueh, Toxicol. Lett., 2008, 179, 130-139.

92 R. Zhang, M. J. Piao, K. C. Kim, A. D. Kim, J. Y. Choi, J. Choi and J. W. Hyun, Int. J. Biochem. Cell Biol., 2012, 44, 224-232.

93 S. W. Ryter and A. M. Choi, Curr. Pharm. Des., 2013, 19, 2747-2756.

94 R. Kiffin, C. Christian, E. Knecht and A. M. Cuervo, Mol. Biol. Cell, 2004, 15, 4829-4840.

95 J. Cadet, T. Delatour, T. Douki, D. Gasparutto, J. P. Pouget, J. L. Ravanat and S. Sauvaigo, Mutat. Res., 1999, 424, 9-21.

96 H. J. Eom and J. Choi, Environ. Sci. Technol., 2010, 44, 8337-8342.

97 K. Ishikawa, H. Ishii and T. Saito, DNA Cell Biol., 2006, 25, 406-411.

98 J. R. Friedman and J. Nunnari, Nature, 2014, 505, 335343.

99 J. S. Teodoro, A. M. Simoes, F. V. Duarte, A. P. Rolo, R. C. Murdoch, S. M. Hussain and C. M. Palmeira, Toxicol. in Vitro, 2011, 25, 664-670.

100 S. Kim, J. E. Choi, J. Choi, K. H. Chung, K. Park, J. Yi and D. Y. Ryu, Toxicol. in Vitro, 2009, 23, 1076-1084.

101 L. Y. Wong, J. Recht and B. C. Laurent, J. Mol. Histol., 2006, 37, 261-269.

102 C. S. Costa, J. V. Ronconi, J. F. Daufenbach, C. L. Goncalves, G. T. Rezin, E. L. Streck and M. M. Paula, Mol. Cell. Biochem., 2010, 342, 51-56.

103 R. Foldbjerg, E. S. Irving, Y. Hyashi, D. S. Sutherland, K. Thorsen, H. Autrup and C. Beer, Toxicol. Sci., 2012, 130, 145-157.

104 N. Singh, B. Manshian, G. J. Jenkins, S. M. Griffiths, P. M. Williams, T. G. Maffeis, C. J. Wright and S. H. Doak, Biomaterials, 2009, 30, 3891-3914.

105 J. Liu, Z. Wang, F. D. Liu, A. B. Kane and R. H. Hurt, ACS Nano, 2012, 6, 9887-9899.

106 S. Chernousova and M. Epple, Angew. Chem., Int. Ed., 2013, 52, 1636-1653.

107 S. J. Yu, J. B. Chao, J. Sun, Y. G. Yin, J. F. Liu and G. B. Jiang, Environ. Sci. Technol., 2013, 47, 3268-3274. 